\title{
Seagrass Importance in Food Provisioning Services: Fish Stomach Content as a Link between Seagrass Meadows and Local Fisheries
}

\author{
Maricela de la Torre-Castro*1, Johan S. Eklöf ${ }^{1}$, Patrik Rönnbäck ${ }^{1,3}$ and Mats Björk ${ }^{2}$ \\ ${ }^{1}$ Department of Systems Ecology, Stockholm University, SE-106 91 Stockholm, Sweden; ${ }^{2}$ Department \\ of Botany, University of Stockholm, S-106 91 Stockholm, Sweden; ${ }^{3}$ The Beijer International Institute of \\ Ecological Economics, the Royal Swedish Academy of Sciences, Box 50005, SE-10405, Stockholm, Sweden
}

Keywords: Fisheries, Siganus sutor, Leptoscarus vaigiensis, seagrass, stomach content, East Africa, Zanzibar, Chwaka Bay, bait, local ecological knowledge, ecosystem services

\begin{abstract}
The links between ecosystem processes and functions and ecosystem services (i.e. the human benefits from those) are elusive. In this paper, the food provisioning service of seagrass meadows is operationalized through the study of the stomach contents of 13 important commercial fish species in Chwaka Bay, Zanzibar. Using local fishers' knowledge on bait, scientific knowledge about the structure of the meadows (associated flora and fauna), stomach content analysis and multivariate statistics, the food provisioning service associated with seagrasses and its importance for fish (as important diet component) and for humans (in small-scale artisanal fisheries) are described. The study presents the food items for 13 commercial fish species identified at the lowest possible taxonomical level and compares with previous literature findings. In addition, differences in stomach contents of Siganus sutor and Leptoscarus vaigiensis caught with both drag-nets and dema basket traps are investigated in order to explore bait presence and indirectly evaluate fishers' knowledge on bait preference. The results show that most of the items consumed by commercial fishes are associated with seagrass beds and that there are clear indicators that the bait traditionally used seems to be effective. The paper elaborates on the consideration of seagrass ecosystems in a holistic perspective, the difficulties in valuation of ecosystem services and finally the crucial importance of these aspects for human well-being and sustainability in coastal communities of the Western Indian Ocean.
\end{abstract}

\section{INTRODUCTION}

Small-scale fisheries in the Western Indian Ocean region (WIO) constitute a crucial activity supporting coastal livelihoods and providing basic animal protein. Catches derived from traditional fisheries may contribute as much as $95 \%$ of the total fish catch in some countries in the region such as Tanzania (Jiddawi \& Öhman 2002). These small-scale fishing activities normally take place in shallow coastal waters, where most of the fish caught have links to the different ecosystems present in the seascape, i.e., mangroves, seagrasses and coral reefs. The importance of seagrass ecosystems in the seascape has commonly been overlooked, but their significance in the WIO region has recently been stressed in both ecological and social terms (e.g. Ochieng \& Eftermeijer, 1999; Gullström et al., 2002; de la Torre-Castro \& Rönnbäck, 2004; Dorenbosch et al. 2005; Uku, 2005; de la TorreCastro, 2006). Seagrass ecosystems provide a large number of ecosystem goods and services, 
such as habitat and nursery ground provision, fisheries production, erosion control, water quality maintenance and enhancement of biodiversity (e.g. Fortes, 1989; Duarte, 2000; Green \& Short, 2003; de la Torre-Castro, 2006). In the WIO, seagrasses greatly contribute to coral reef adult fish densities and rank highest, together with corals, as nursery habitat (Dorenbosch et al., 2005).

The objective of this study is to illustrate one specific ecosystem service associated with seagrass ecosystems, i.e. the food provisioning service, which supports local fish populations and in turn benefits coastal communities in Zanzibar. Ecosystem services are considered here in the widest sense as "the benefits people obtain from ecosystems" (Millennium Ecosystem Assessment 2003). The ecosystem services were operationalized in two ways, by assessing (i) the ecological importance of the meadows as providers of food items for fish (the plant itself, and its associated algal and animal communities) and (ii) the importance of the meadows as providers of bait and fishing grounds for the local fishers. Specifically, analyses of the stomach content of some economically important seagrass fish species were conducted, identifying their main sources of food, and thereby indirectly inferring why these fish species are associated to fishing grounds dominated by seagrasses. Furthermore, the importance of the locally-used fish bait for basket trap (dema) fisheries was investigated by comparing the occurrence of bait in the stomach content of fish caught with drag-nets and baited traps.

To date, relatively few studies have been published on the diet of fish species in the region (e.g. de Troch et al., 1998; Almeida et al. 1999; Almeida et al. 2001; de Boer et al. 2001) and seagrass consuming fish are rarely analyzed (e.g. Lugendo et al., 2006). Consequently there is also a general lack of information on specific food items that commercially important fish species depend on (see for example www.fishbase.org). The results of this paper contribute to the identification of the food items at the lowest possible taxonomical level and it links further to seagrass ecosystem importance for livelihoods and subsistence.

\section{FOOD ITEMS ASSOCIATED WITH SEAGRASS ECOSYSTEMS}

\section{Seagrasses, benthic macroalgae and epiphytes}

Apart from being an important structural component in coastal habitats, seagrass beds are a source of food for many marine organisms. The seagrass plant itself can be consumed directly by turtles, dugongs, fish and sea urchins (Valentine et al., 2002; Eklöf et al. 2008), but associated epiphytes are also important indirect food sources for fishes in seagrass ecosystems. Epiphytes (i.e. any organisms that grow on the surface of plants) are commonly found on all seagrass species, and their distribution and diversity is affected by several factors, such as the morphology of the seagrass species, the specific life span of the colonized part of the seagrass, the position of the colonized part within the seagrass canopy (affecting parameters like light and nutrient availability), depth and ambient nutrient levels, etc (e.g. Uku \& Björk, 2005).

Of the seagrass epiphytes found in this region epiphytic algae are the most abundant, consisting of a variety of species. Red coralline crusts (e.g. Hydrolithon farinosum) are very common, especially on leaves of the seagrass Thalassodendron ciliatum (Uku \& Björk 2001). Other common epiphytes are Enteromorpha spp., Ulva spp., Sphacelaria furcigera, Hypnea ramulosa, Amphiroa rigida and Ceramium flaccidum that are found on the stems of seagrasses, together with dense red algal turfs and different crustose coralline algae (Semesi, 1988;Uku \& Björk, 2001).

The epiphytic biomass on seagrasses can be substantial, e.g. ranging from 30 to $40 \%$ of the fresh weight of Thalassodendron shoots in relatively pristine sites and nutrient rich areas in the WIO region, respectively (Semesi, 1988; Uku \& Björk, 2001).

\section{Seagrass associated invertebrate communities}

Seagrass beds, even though relatively species-poor in terms of seagrass diversity, host highly diverse and abundant animal communities. Both abundance, 
biomass and diversity of animal communities, e.g. benthic infauna, epifauna and nekton, is several orders of magnitude higher (up to 100,000 s of ind. $\mathrm{m}^{-2}$ ) in seagrass beds than in unvegetated areas (e.g. Bostrom \& Bonsdorff 1997; Arrivillaga \& Baltz 1999, Paula et al., 2001; Eklöf et al., 2005). This is often attributed to refuge from predation (Hindell et al., 2000, Salita et al., 2003) and the presence of food (Connolly, 1994; Bologna \& Heck, 1999), and is in turn affected by seagrass properties such as species diversity (Somerfield et al., 2002) and shoot density (Webster et al., 1998). There is often also a marked difference in animal community composition in seagrass beds, which in tropical areas include crustaceans (amphipods, isopods, copepods), polychaetes, nematodes, echinoderms and molluscs (Somerfield et al., 2002; Eklöf et al., 2005).

\section{Bait provision ("gozi", invertebrates and macroalgae)}

In the WIO, bait selection is a critical factor for many artisanal fisheries. The stationary dema basket trap fisheries are particularly dependent on bait quality and abundance for good catches. Dema basket traps are hexagonal wooden cages of varying sizes that are placed in different habitats along the seascape. However, in certain places of the WIO such as the Quirimbas Archipelago (Mozambique) and Chwaka Bay (Zanzibar, Tanzania) dema fisheries are considered to be seagrass-associated; fishermen specifically place their traps in seagrass meadows and target seagrass associated fish (Gell \& Whittingon, 2002; Bandeira \& Gell, 2003; de la Torre-Castro \& Rönnbäck, 2004). Bait selection depends on the fish targeted and the fishermen have extensive ecological knowledge associating fish species with different food items (de la Torre-Castro, 2006). Benthic invertebrate feeders are normally lured by a collection of echinoderms such as brittle stars (Ophiuroidea) and star fish (Asteroidea). Herbivorous fish are attracted by different bait items such as algae and sponges (e.g. Laurencia spp., Ulva spp., Porifera). Red and green algae are largely preferred; among the most common species are Hyphnea cornuta, Chondrophycus papillosus, Leveillea spp., Ceramium spp., Centroceras clavulatum,
Cladophora vagabunda, Chaetomorpha crassa and Enteromorpha kylinii. In Chwaka village, dema traps are normally baited with a mixture containing a symbiotic sponge (Porifera: Halocondriidae spec. nov; local name "gozi") and the macroalgae Laurencia papillosa (Rhodophyta). The symbiotic sponge "gozi" (meaning skin) is abundant in particular areas of the Bay (see also de la TorreCastro \& Rönnbäck 2004), forming a layer over the seagrass leaves (mainly Thalassia hemprichii and Cymodocea spp.). Fishers collect it by hand and place bunches of seagrass with the epiphytic sponge and associated algae (fleshy, filamentous and encrusting) in the dema traps. Fishers report that the mixed bait is very efficient when attracting Siganus spp. (seagrass rabbit fish) and Lepstoscarus vaigiensis (seagrass parrot fish).

\section{MATERIALS AND METHODS}

\section{Study area}

This study was conducted in Chwaka Bay, an intertidal water body located on the east coast of Unguja Island (Zanzibar, Tanzania $6^{\circ} 13-25^{\prime} \mathrm{S}$ and $39^{\circ} 37-58^{\prime}$ E, Fig. 1). The area is a seagrass dominated shallow bay of about $50 \mathrm{~km}^{2}$ with circulation patterns dominated by semidiurnal tides. There are eleven reported seagrass species in the area, among others Thalassia hemprichii, Cymodocea serrulata, $C$. rotundata, Halodule uninervis, $H$. wrightii, Thalassodendron ciliatum, Syringodium isoetifolium, Enhalus acoroides and Halophila ovalis. The diversity of fleshy, filamentous and calcareous algal communities is also high in similar settings of the WIO (Coppejans et al., 1992). The general topography in Chwaka Bay is complex and composed of a series of channels and banks in which fisheries and navigation takes place. Seagrasses are abundant in most of the grounds and fishermen divide the Bay into different fishing grounds with specific local names. Areas with sparse seagrass coverage are not popular for fishing, which is reflected in the low fishing pressure and small catches from these areas (Hammar, 2005; de la Torre-Castro, unpublished data).

Seven villages are situated along the coast and the local population (about 10,000 persons 


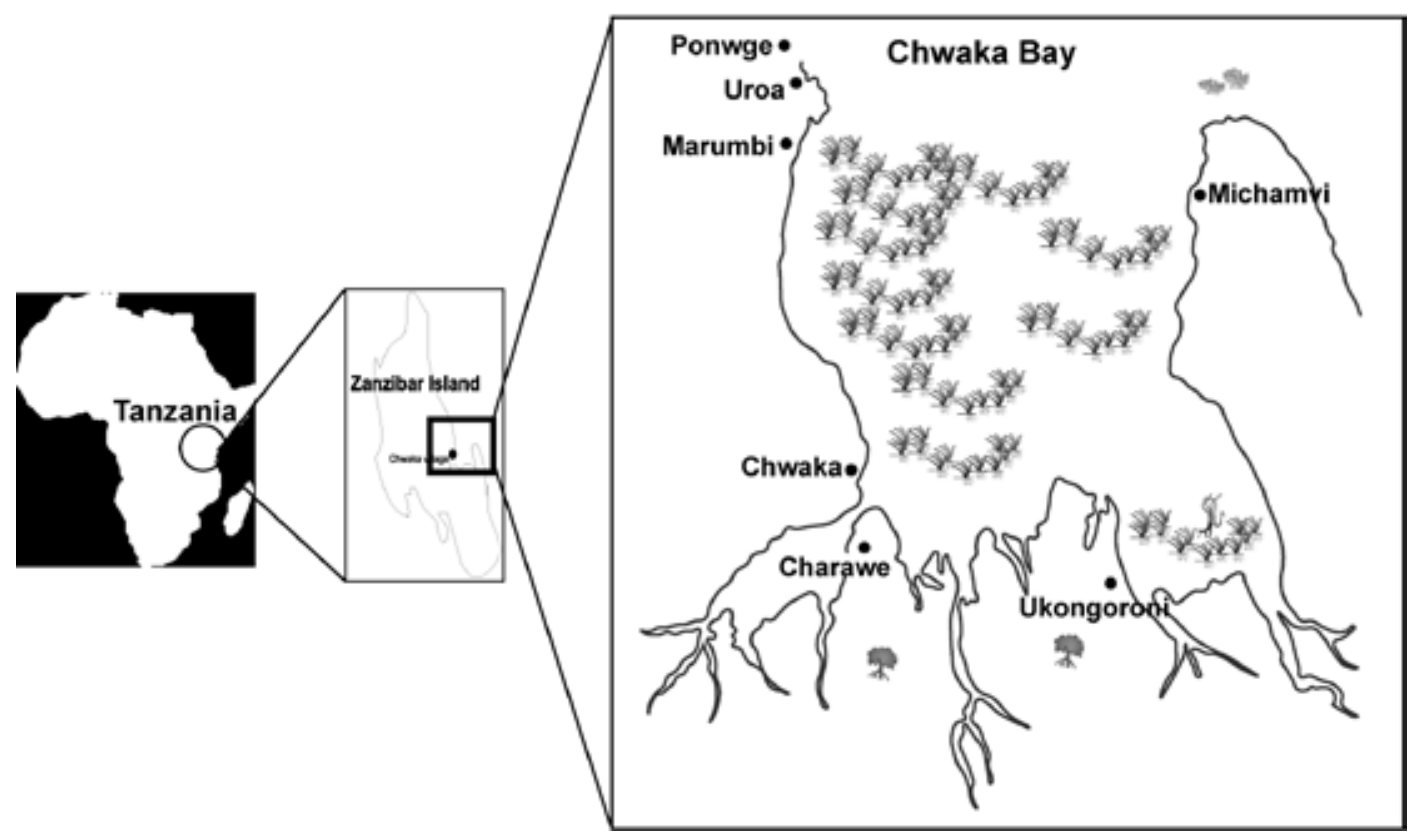

Fig. 1. Chwaka Bay, Zanzibar, Tanzania (6 6-13' S, 39 ${ }^{\circ}$ 24-31' E) with its seven surrounding villages. The local market where the samples were taken is placed in Chwaka village. Bait collection of "gozi" is normally done in the seagrass meadows close to Charawe

total (URT, 2002), relies heavily on fisheries as the primary economic activity and animal protein source. Fish markets are located in the Uroa, Marumbi and Chwaka villages.

\section{Fish collection}

A total of 192 fish representing 13 species were caught by local fishermen from Chwaka village on eight specific occasions in June, 2003. The fishes were bought directly from the fishermen upon arrival at the market. Out of these, 117 were caught using drag-nets and 75 using dema traps. The fishermen were interviewed and they verified that the traps had been baited with the symbiotic sponge "gozi" (described earlier). Fish species were selected based on fishermen's views of their commercial and subsistence importance. The species and the sample numbers are shown in tables 1 and 2.

\section{Stomach content analysis}

Fish were weighed (grammes fresh weight) and measured to the nearest millimetre (total length T.L. and fork length F.L.). They were identified to species level and the stomach contents to the lowest possible taxonomical level using standard taxonomic literature (Fischer \& Bianchi, 1984;Smith \& Heemstra, 1986; Whitfield, 1998; Terashima et al., 2001; Oliveira et al., 2005).

All fishes were dissected and the stomachs removed. The stomachs were preserved in $10 \%$ formalin and stored in $80 \%$ ethanol. The stomach content was then placed in a petri dish and identified into the following categories using a stereo-microscope. Prey animals were classified to phylum (Bryozoa, Echinodermata, and Sipunculida), class (Oligochaeta, Polychaeta, Gastropoda, Bivalvia, Polyplacophora, and Hydrozoa), subclass (Copepoda), infraorder (Caridea, Brachyura), order (Cumacea, Tanaidacea, Amphipoda, and Isopoda), fish and parasites (intestinal worms). Plant material was categorised as seagrass and algae (separated into genus). The remaining categories were sand, detritus, mixed crustaceans (pieces of crustaceans), shells (shell pieces from molluscs), detritus and unidentified material.

The volumetric quantity of each food category was estimated by visual estimation using gridlines $(2.5 \times 2.5 \mathrm{~mm})$, i.e. the volume of the total stomach content was set at $100 \%$, and the volumetric proportion of each food category was estimated by eye (see Hyslop, 1980 and references therein). 
This method was chosen as it has been successfully used in similar studies (Nakamura et al., 2003, de la Moriniere et al., 2003) and is an estimation of biomass, whereas a gravimetric method would have been difficult to conduct due to the fragmented state of some of the food categories (seagrass, detritus and algae in particular), and would have increased the risk of overestimating the importance of largesized prey and underestimating the importance of small prey (Hyslop, 1980). From the total 192 stomachs, 130 were possible to analyze, while the remaining were discarded due to the extreme pulverized material found.

\section{Statistical analysis}

Multivariate statistics were performed using PRIMER 5 for Windows v5.2.9 (Copyright $^{\circledR}$ PRIMER-E Ltd). Bray Curtis similarity coefficient was used in all cases following the procedures described in Clarke \& Warwick (2001).

Differences and similarities in stomach contents between fish were visualized using cluster and nonmetrical multidimensional analysis (MDS). Mean samples were used to perform the analysis. All individuals were pooled by species and the entry data was based on the information from Table 2. According to the general literature (Fischer \& Bianchi, 1984;Smith \& Heemstra, 1986; Whitfield, 1998; Terashima et al., 2001; Oliveira et al., 2005) fishes were further classified into four different trophic groups: BI - benthic invertebrate feeders, BIF - benthic invertebrate feeders that may also eat fish especially when adults, HA - herbivorous algal feeder, and HS - herbivorous seagrass feeder. The categories were plotted in the MDS to analyze the similarities and discrepancies between the reported food items from literature data and the results of this study.

To test for differences in stomach contents depending on fishing gear used, analysis of similarities (ANOSIM) was used, whereas to determine the contribution of the different food items to the overall differences a similarity percentages routine (SIMPER) was performed. The two species selected to perform this analysis were Siganus sutor and Leptoscarus vaigiensis, since they are the target species of dema fishers, being highly important for the subsistence economy and dietary protein supply. All individuals caught of these two species were used in the analysis.

All analyses were conducted using $4^{\text {th }}$ root transformed data. The ANOSIM routine was used to test overall differences based on the R-statistic (see Clarke \& Warwick 2001, chapter 6). In the analysis using all species, one-way ANOSIM was used to test each factor separately (trophic group and gear) and two-way ANOSIM was used to test the factors together. To determine the overall differences of bait in the two selected species, one-way ANOSIM was used.

\section{RESULTS}

The general characteristics of the investigated fish are found in Table 1 below.

Table 1. Basic characteristics of the sampled fish (Chwaka Bay, Zanzibar). T.I.= average total length; F.I.= average fork length; Weight $=$ average fresh weight in grammes

\section{A. Drag - net}

\begin{tabular}{lrcccrrr}
\hline Species & n & T.l. $(\mathbf{c m})$ & s.d. & F.l. $(\mathbf{c m})$ & s.d. & Weight (g) & s.d. \\
\hline Cheilinus trilobatus & 7 & 19,74 & 1,50 & 19,74 & 1,50 & 143,86 & 37,56 \\
Gerres oyena & 9 & 11,71 & 0,44 & 10,04 & 0,40 & 19,44 & 1,88 \\
Hipposcarus harid & 4 & 14,25 & 2,00 & 13,70 & 1,94 & 45,25 & 26,23 \\
Lethrinus lentjan & 5 & 15,96 & 1,52 & 14,84 & 1,39 & 55,40 & 17,24 \\
Lethrinus mahsena & 7 & 12,54 & 1,45 & 11,59 & 1,16 & 26,43 & 7,70 \\
Lethrinus variegatus & 2 & 14,85 & 0,21 & 13,70 & 0,28 & 43,50 & 3,54 \\
Leptoscarus vaigiensis & 10 & 18,37 & 1,73 & 18,37 & 1,73 & 83,50 & 24,34 \\
Lutjanus monostigma & 10 & 17,88 & 1,92 & 17,18 & 1,86 & 87,80 & 30,24 \\
Parupeneus indicus & 5 & 17,52 & 3,78 & 15,60 & 3,40 & 79,00 & 61,91 \\
Parupeneus macronema & 4 & 22,11 & 5,45 & 18,39 & 2,75 & 107,88 & 46,10 \\
Siganus sutor & 18 & 12,72 & 1,73 & 12,16 & 1,59 & 25,11 & 10,01 \\
\hline
\end{tabular}


Contd. from previous page

B. Basket traps (dema)

\begin{tabular}{lcccccrr}
\hline Species & n & T.l. $(\mathbf{c m})$ & s.d. & F.l. $(\mathbf{c m})$ & s.d. & Weight $(\mathbf{g})$ & s.d. \\
\hline Cheilinus trilobatus & 5 & 15,56 & 1,22 & 15,56 & 1,22 & 63,80 & 15,40 \\
Lethrinus lentjan & 3 & 17,30 & 1,40 & 16,20 & 1,06 & 72,00 & 12,17 \\
Leptoscarus vaigiensis & 7 & 23,67 & 1,62 & 23,67 & 1,62 & 180,29 & 34,37 \\
Parupeneus macronema & 8 & 16,40 & 0,75 & 13,93 & 0,88 & 47,75 & 7,68 \\
Scarus ghobban & 8 & 16,86 & 2,52 & 16,81 & 2,43 & 87,29 & 38,13 \\
Scolopsis ghanam & 4 & 13,08 & 0,71 & 12,23 & 0,66 & 31,00 & 2,94 \\
Siganus sutor & 13 & 26,25 & 27,84 & 24,92 & 28,10 & 81,00 & 40,70 \\
\hline
\end{tabular}

\section{Generalities of fish stomach contents}

A total of 44 different food categories were identified in the stomachs of the 13 fish species (Table 2). Numerically, animal prey was dominant with 25 different taxa found, including eight taxa of crustaceans. Plants were represented by 14 taxa, including 13 algae (with representatives from all three major groups Phaeophyta, Rhodophyta and Chlorophyta) identified to genus level. Red algae dominated, with eight taxa included. Seagrasses, which constituted the last plant taxa, were pooled into one group due to difficulties in separating different genus and species. The third major group ('Others') consisted of five non-taxonomical groups (including eggs, sand, detritus, shells and unidentified material).

In terms of relative importance of food items for all species (when pooling the two gear types and ignoring $15.8 \%$ of material which remained unidentified), crabs (Brachyura) dominated (13.4 $\%)$, closely followed by detritus $(10.3 \%)$, seagrass (9\%), Amphipoda (5.8\%) and Gastropoda (5.7\%). When analysing fish caught in dema traps alone, the largest identified food items were "gozi" $(10.1 \%)$, seagrass $(9.8 \%)$, Chaetomorpha spp. (9.8\%), Brachyura $(9.3 \%)$ and Laurencia spp. (7.3\%). It is likely that a large fraction of the unidentified material (24.8\% of total food items found in dema caught fish) actually constitutes partly digested "gozi", which is relatively difficult to identify. For fish caught using drag-nets, the dominating items (ignoring $8.4 \%$ unidentified) were Brachyura (16.9 $\%$ ), detritus (13.7\%), Amphipoda ( $8.3 \%$ ), seagrass $(8.3 \%)$ and Gastropoda (8.2\%).
The percentage of individuals per species containing seagrass, "gozi", epiphytes and macroalgae as well as detritus is shown in table 3 .

\section{Separation of fish species based on stomach contents}

The results of the multivariate analysis showed differences between species according to trophic groups (Fig. 2). As displayed in the MDS plot, there was an overall grouping into herbivores and invertebrate/fish feeders. A stress of 0.16 provides a good ordination value. However, the herbivorous species Hipposcarus harid and the benthic invertebrate and fish eater Lutjanus lentjan did not follow the expected patterns reported in the literature; $H$. harid was positioned away from the herbivorous group and L. lentjan (at least when caught with dema) positioned very close to the herbivorous group. This suggests that L. lentjan may be attracted by the bait and that both L. lentjan and $H$. harid behave in a more generalist way than previously reported in the literature. However, very few data were collected in order to provide conclusive evidence of a broader diet in these two species.

In general, the invertebrate feeders (BI) and invertebrate/fish feeders (BIF) formed a tighter cluster than the herbivorous species. The latter indicates similar diets for all the BI and BIF species. In the analysis of gear effect on stomach content, both the MDS (Fig. 2) and cluster analysis (Fig. 3) showed a clear separation into two main groups: a) the various herbivorous species and $b$ ) the various invertebrate and fish feeder species. The similarity plots also show differences in stomach content 


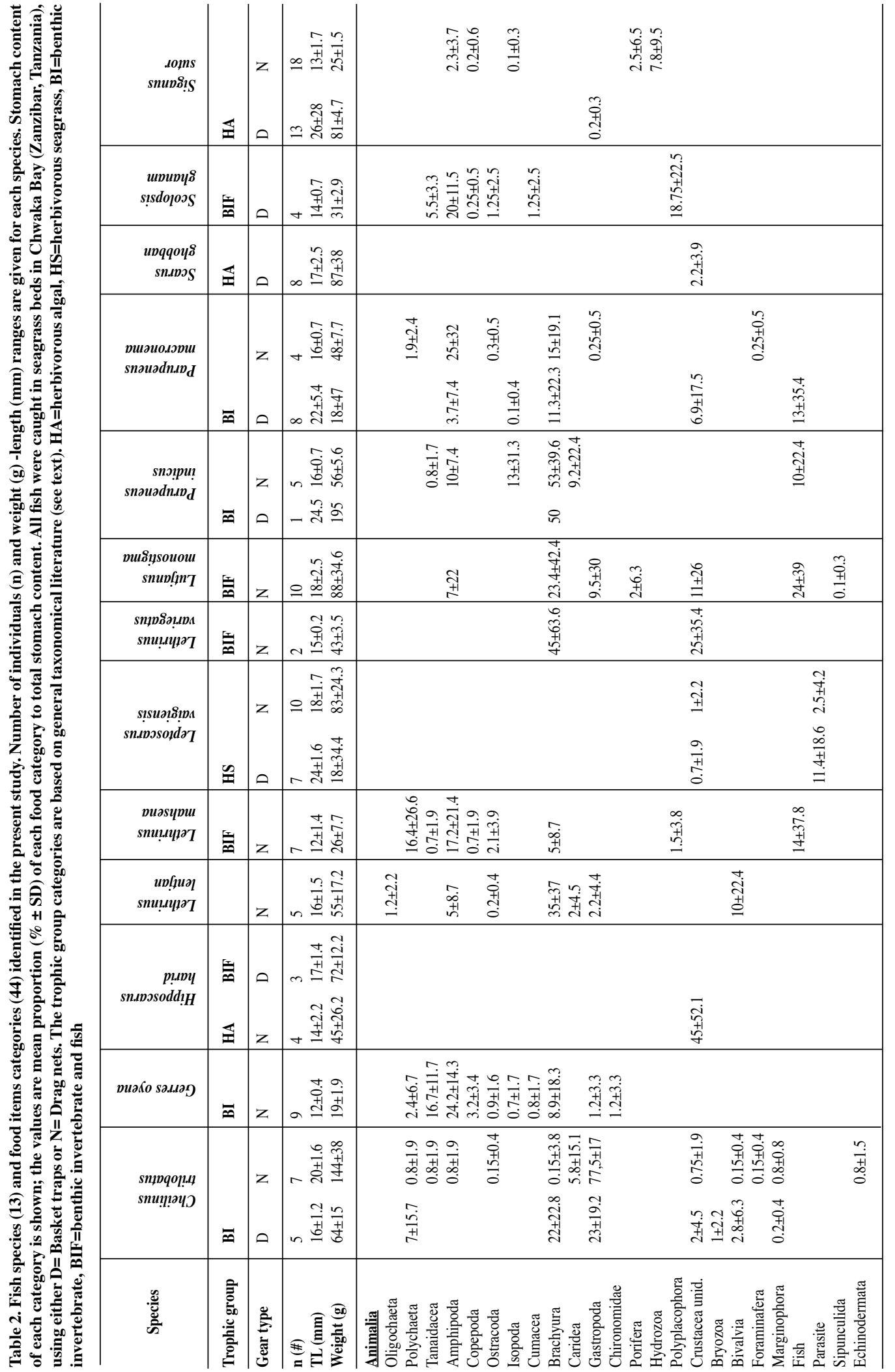




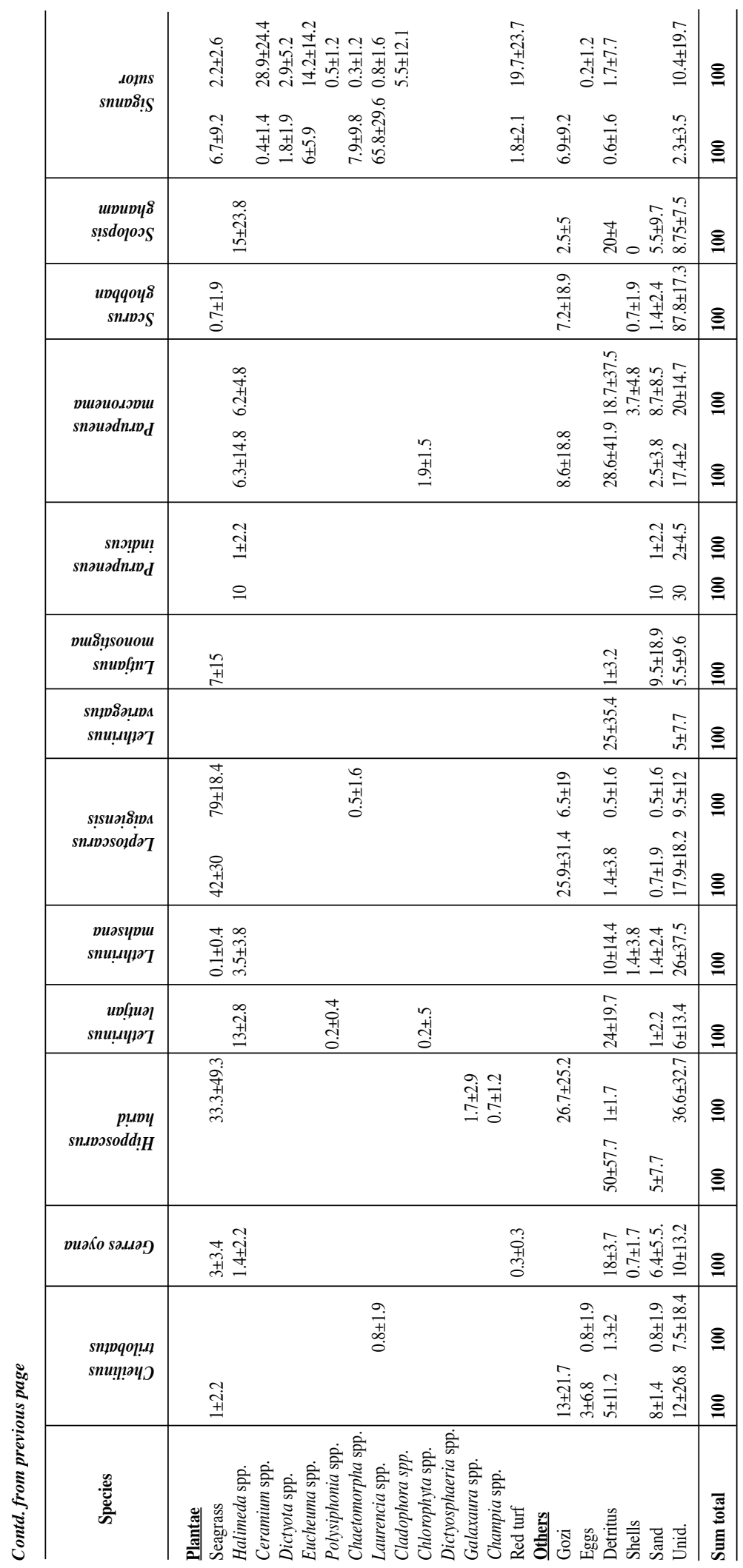




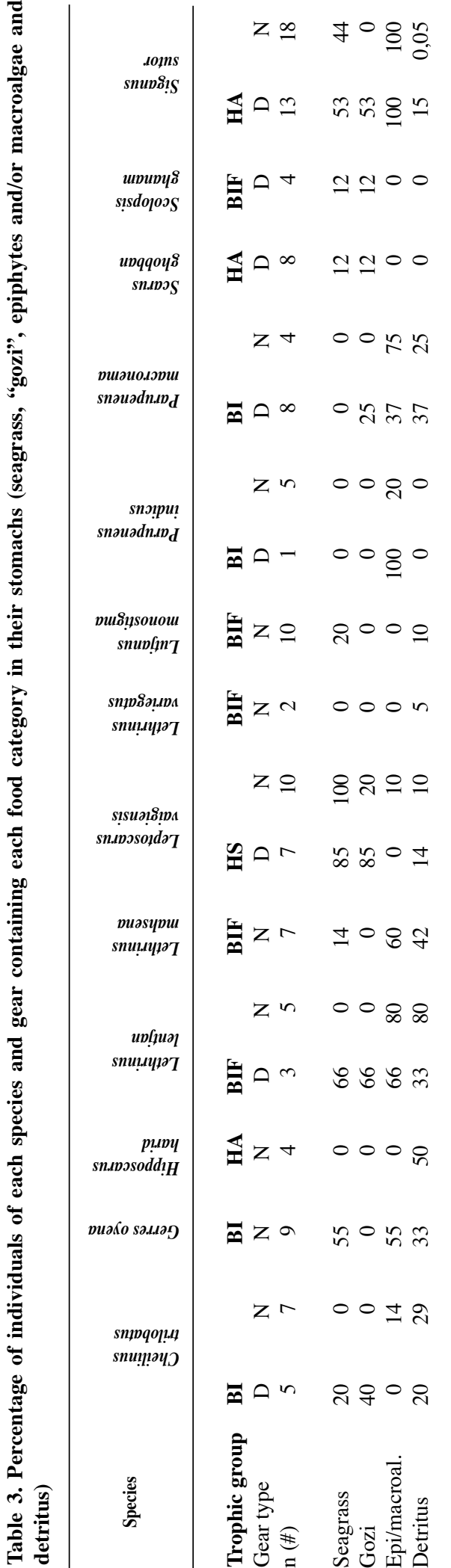

between fish caught using dema traps or net. This separation is very distinct for the herbivorous species, and highly variable for the invertebrate feeding species. In the invertebrate feeder group a clear gear separation is found for Parupeneus indicus, while less clear patterns are found for the rest of the species (Fig. 2 and 3). The cluster analysis (Fig. 3) clearly shows, that with the exception of L. lentjan and $H$. harid, a clear separation is found following the expectations based on the literature and different gear used. A main bifurcation takes place at about $30 \%$ similarity.

Results from the ANOSIM test gives higher values for trophic group (arranged according to literature) (Global $\mathrm{R}=0.263, \mathrm{p}=0.01$ ) than for gear (Global $\mathrm{R}=0.13$; $\mathrm{p}=0.06$ ). The ANOSIM test was also performed grouping the fish according to the results of our data (Cluster analysis, Fig. 3) considering two main groups i.e. herbivorous branch (S. sutor, L. vaigiensis, L. lentjan, $S$. ghobban) and invertebrate/fish feeders branch (remaining species). The global $\mathrm{R}$ in this case is as high as $0.5(\mathrm{p}=0.002)$. However, the two-way analysis shows slight differences compared to the one-way analysis. A slightly higher significance with both combined factors was obtained for the trophic groups (averaged across all gear groups) (Global $\mathrm{R}=0.309, \mathrm{p}=0.016$ ); while for the gear groups (averaged across all trophic groups) the global value is almost identical but the significance is clearly lower (Global $\mathrm{R}=0.112, \mathrm{p}=0.2$ ).

In terms of the contribution of different stomach contents categories to the results, the SIMPER routine shows that the average dissimilarity value between the benthic invertebrates/fish feeders (BIF) and general herbivorous $(\mathrm{H})$ is 70 $\%$ (see Fig.3). The main items contributing to the dissimilarity are Brachyura (8\%), seagrass $(8 \%)$, "gozi" (6.6\%), detritus (5.4\%), Amphipoda (5.2\%), crustacean mix (5\%) and Halimeda spp. (4.5\%). The main differences between algal feeders and seagrass feeders (average dissimilarity $60 \%$ ) were determined by seagrass (14\%), parasites $(11.2 \%)$ and "gozi" (8\%). A dissimilarity of $65 \%$ was found between gears (dema and net); the items determining the differences were "gozi" (8\%), Brachyura (7 $\%$ ), seagrass (6.3\%), Amphipoda (5.8\%), detritus $(5.7 \%)$ and crustacean mix $(5.3 \%)$. 


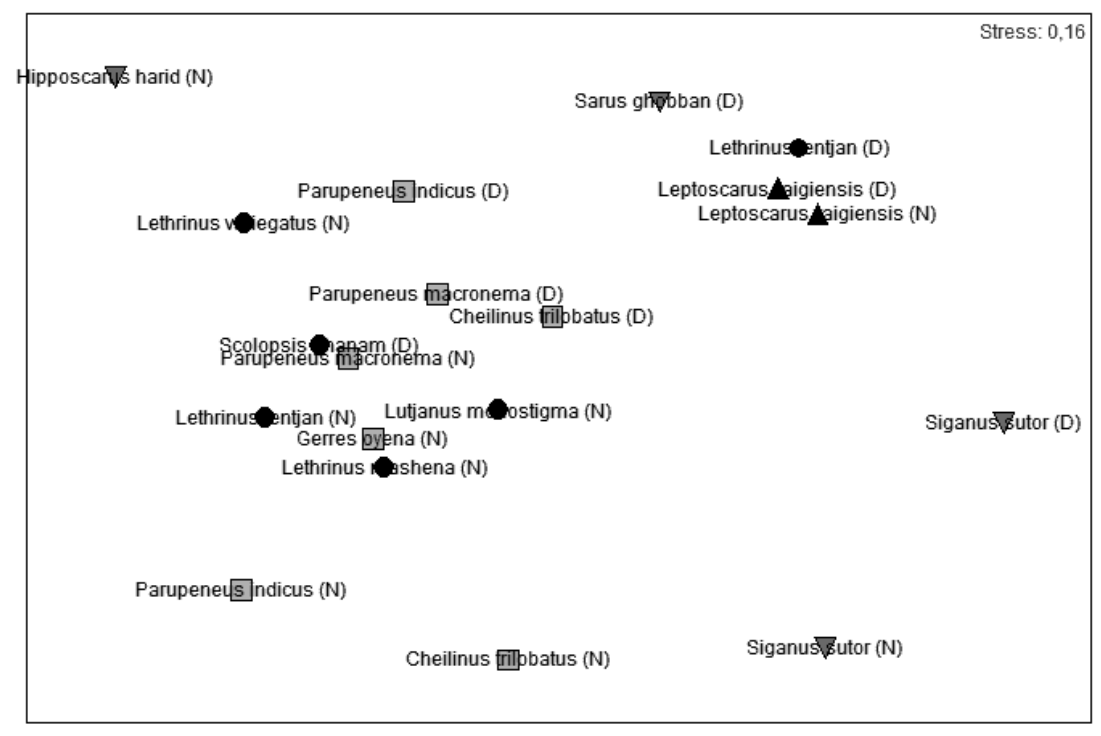

Fig. 2. MDS plot illustrating the differences between stomach contents of all analyzed species (13) from Chwaka Bay, Zanzibar, Tanzania. The trophic groups according to general taxonomical literature are shown. Two main groups are distinguished, the herbivorous feeders group and the invertebrate/fish feeder group. For each species dema basket traps (D) and drag net $(\mathrm{N})$ caught fishes are shown

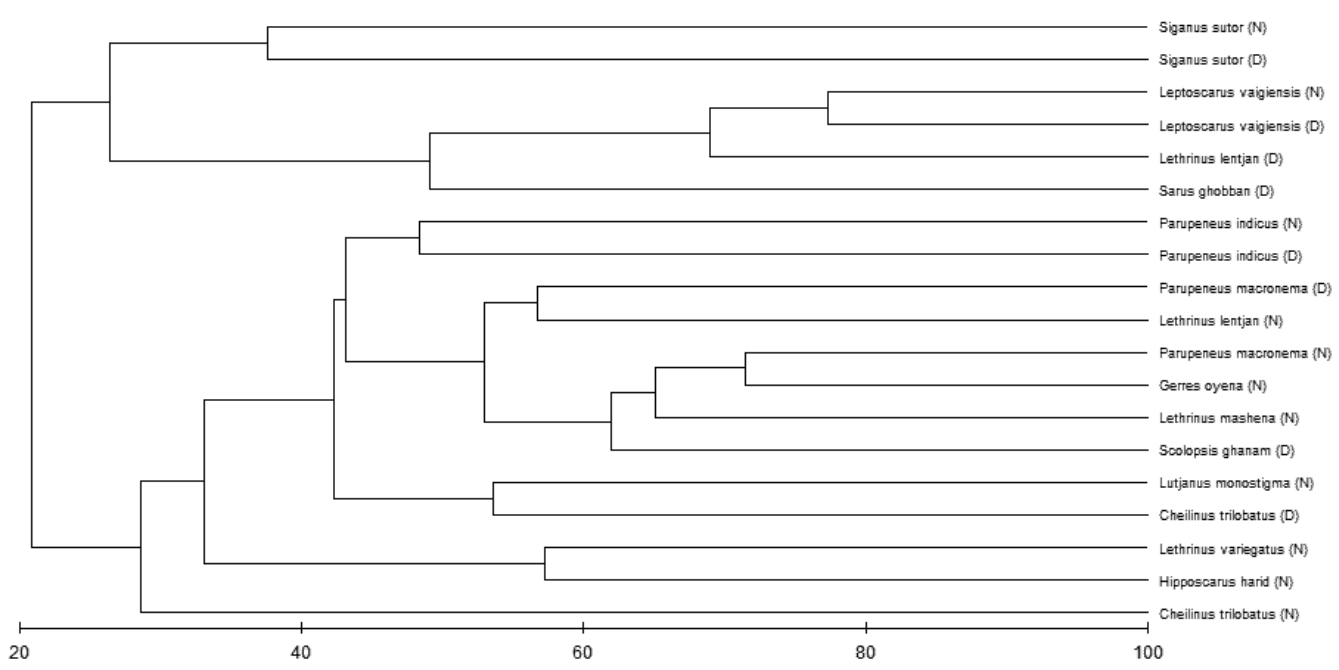

Similarity

Fig. 3. Cluster diagram of the stomach contents of all analyzed species (13) from Chwaka Bay, Zanzibar, Tanzania. For each species dema basket traps (D) and drag net $(\mathrm{N})$ caught fishes are shown

Differences in stomach contents between Siganus sutor and Leptoscarus vaigiensis for different gears

There are clear differences in the stomach contents of the same species caught by different gears (dema and net) (Fig. 4 and 5). Both stress values of 0.13 and 0.1 respectively provide good ordination values. The differences and group separation are strongest for Siganus sutor (Fig. 4) with cluster analysis and MDS plots showing similar results. The MDS shows two completely separate 
aggregations. Cluster analysis (Fig. 3) shows clear bifurcations into dema and net branches for almost all species. The results are confirmed by ANOSIM which provide a highly significant global value (Global R=0.887, $\mathrm{p}<0.001$ ).

The difference between gears for Leptoscarus vaigiensis is clear but not as strong as for $S$. sutor (Fig. 5). The MDS plot and the cluster show an acceptable but not perfect group separation. The MDS plot shows that two samples taken by net are closer to the dema grouping and the same result is found in the cluster analysis where a strong bifurcation takes place, but two net samples fall into the dema aggregation. The ANOSIM test provided a lower global value for $L$. vaigiensis compared to the $S$. sutor value (Global $\mathrm{R}=0.315 \mathrm{p}=0.08$ ). However, if one of the net samples falling into the dema grouping is omitted, the global $\mathrm{R}$ value increases as much as 0.47 .

The SIMPER analysis shows that the food

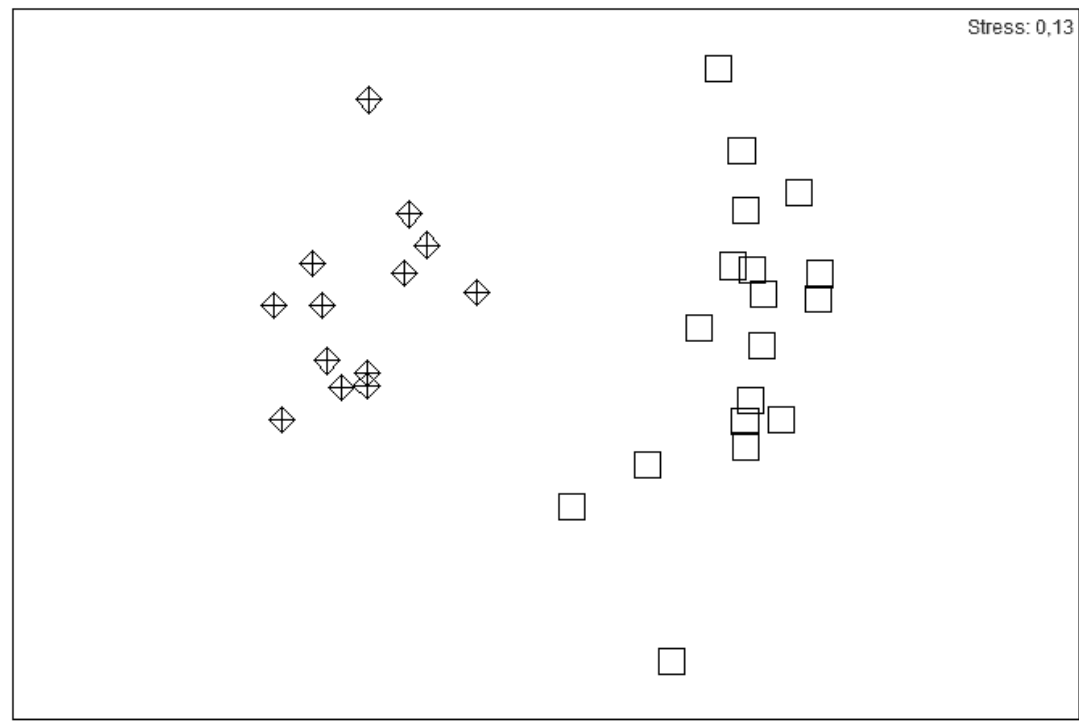

Fig. 4. MDS plot showing differences in stomach contents of Siganus sutor for fish caught with dema basket traps $(\diamond)$ or with drag nets () in Chwaka Bay, Zanzibar, Tanzania

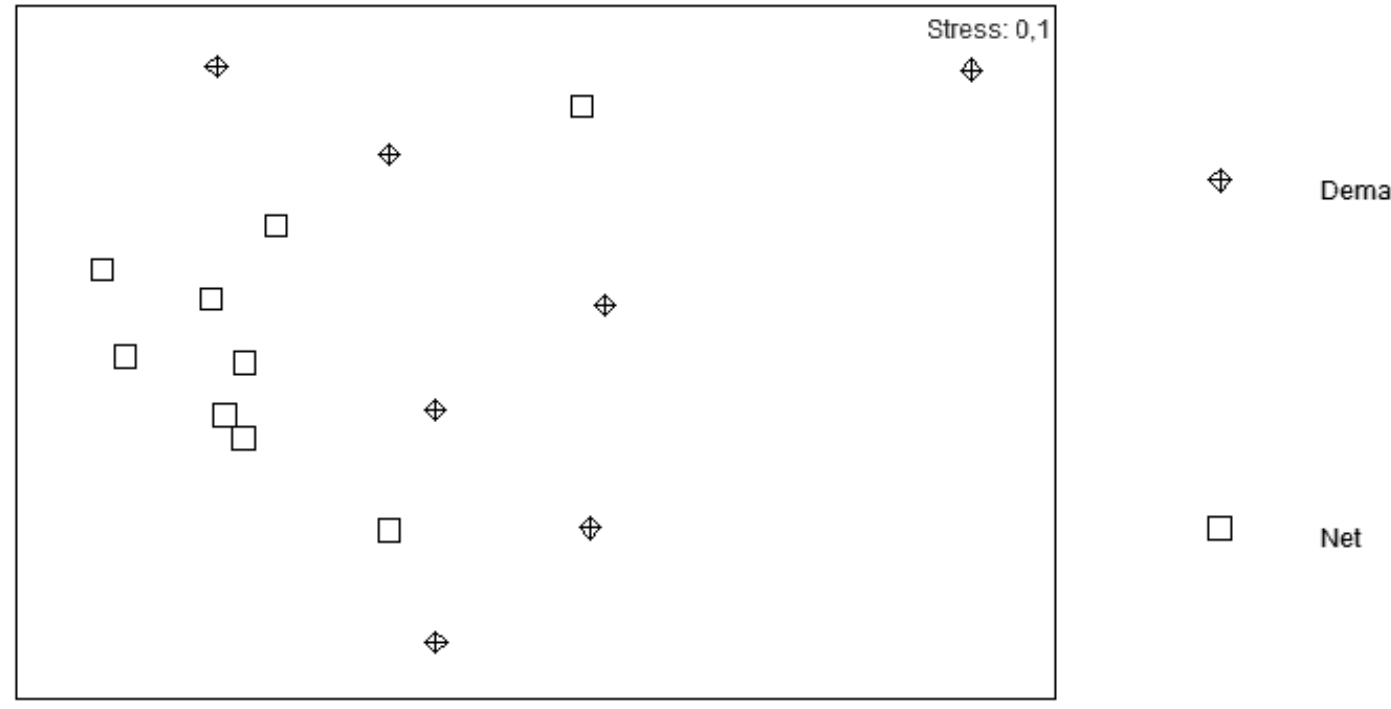

Fig. 5. MDS plot showing differences in stomach contents of Leptoscarus vaigiensis for fish caught with dema basket traps $(\diamond)$ or with drag nets () in Chwaka Bay, Zanzibar, Tanzania 
items contributing to the overall dissimilarities between dema and net for Siganus sutor were varied: Laurencia spp. $17.4 \%$, Ceramium $13.2 \%$, red turft $8.8 \%$, Hydrozoa $7.4 \%$, Chaetomorpha $6.6 \%$, Euchema spp. $6.5 \%$, "gozi” $6.2 \%$, seagrass $5.8 \%$, Dichtyota $4.6 \%$, Amphipoda $4.5 \%$ and Cladophora $3.8 \%$. For the dema group alone, Laurencia spp. contributed with $53.4 \%$ to the similarities.

For Leptoscarus vaigiensis, the main contributors to the overall dissimilarities between dema and net were: "gozi" $29 \%$, Unidentified $18.6 \%$, Parasites $17 \%$, seagrass $14.3 \%$, crustacean mix $7.4 \%$, detritus $6 \%$. For the dema group alone, seagrass contributed $41 \%$ and "gozi" $32 \%$ to the similarities within the group.

\section{DISCUSSION AND CONCLUSION}

\section{Importance of seagrass tissue as a food source versus importance of seagrass ecosystem associated community}

Holistic studies trying to analyze the complete link from ecosystem to human benefits are rare. The results of this study illustrate the value of seagrass ecosystems in providing food for many fish species and the ecosystem service of fish production to humans. Seagrass ecosystems are complex aggregations of flora and fauna, where the main structural component is the seagrass itself. Therefore, an analysis of the food provisioning service of seagrass ecosystems should include the seagrass plants and the associated communities, something which is rarely done.

Seagrasses were found in the stomachs of 65 $\%$ of all fish species studied, both in expected (e.g. L. vaigiensis) and unexpected species (e.g. $L$. lentjan). However, Leptoscarus vaigiensis was the only species that seemed to have a clear preference for seagrass (Tables 2 and 3). Surprisingly, seagrass was found in the stomach contents for L. lentjan, even though it is well known that this species feeds on invertebrates and fish. It is possible that the high seagrass content in the stomachs is related to passive ingestion while feeding on invertebrates or small-sized fishes in the seagrass meadows that the fish uses as foraging grounds. It is also possible that fishes trapped in the demas may consume whatever is available to avoid starvation. However, the number of L. lentjan specimens sampled in this study is very low ( $n=3$ for dema; total $n=8)$ suggesting that more research is needed to clarify a possible seagrass contribution to the diet of this fish.

Another interesting result was the diet of Hipposcarus harid, which consumed mainly unidentified crustaceans, but has previously been reported as an algal feeder (see www.fishbase.org for example). The different members of the family Scaridae pose a challenge for food item identification studies, due to the pharyngeal mill which pulverizes most material beyond recognition.

A total of 13 genera of algae were identified in the fish stomachs. In many other fish stomach content studies of seagrass-residing fish (e.g. de Troch et al., 1998; Almeida et al., 1999), algae have usually been pooled into one or several broader categories (e.g. based on functional groups). The results of the present study, however, demonstrate the ability of identifying algae from stomach content to a very high taxonomic resolution. When using the results of stomach content analyses to increase the understanding of ecological interactions (e.g. food preference of different economically important species), precise and accurate determination of stomach content may be critical for ecosystem service valuation and results extrapolation.

All the plant taxa found in the stomach of the fish (Table 2 and 3) are normally found in seagrass systems in the WIO (e.g. Coppejans et al., 1992; Richmond, 1997; Oliveira et al., 2005). With the exception of Halimeda spp., which is a very common calcareous alga in the area that can form relatively large mono-specific patches (size 3-5 m diameter) within and adjacent to seagrass meadows, all other plant food items are found either on or between seagrass shoots. About $60 \%$ of all sampled fish species had epiphytes and/or macroalgae in their stomachs (Table 3 ). Regarding the animal food items, few systematic studies have investigated animal communities associated to seagrass ecosystems in the study area. Eklöf et al., (2005) analyzed infauna invertebrate communities $(>0.5 \mathrm{~mm})$ in seagrass meadows in Chwaka Bay. Based on the results of this study, $75 \%$ of all food items found in the fish stomachs were also found 
in the seagrass meadows. Some exceptions were Porifera, Hydrozoa and Bryozoa, which are not considered infauna but are well known to be parts of tropical seagrass communities (Hemminga and Duarte, 2000). They have also been identified as food items in fish stomachs in similar tropical bays in the WIO e.g. in Gazi Bay, Kenya (de Troch et al., 1998).

The present study illustrates that in this particular setting, herbivorous, invertebrate and invertebrate/ fish feeders are all present and consume food items from the surrounding seagrass meadows. de Boer et al., (2001) found a dominance of invertebrate feeders and low numbers of piscivorous in meadows of Inhaca Island, Mozambique, subjected to constant pressure by the artisanal fishery. Although the sample numbers of this study are low, similar results were obtained.

Although the food provisioning service is rather straightforward, i.e. from the seagrass ecosystem to fish, and from fish to humans; understanding and illustrating it may be difficult. The present study highlights the link using quantitative ecological data and analyzing the seagrass ecosystem from a holistic perspective considering not only the seagrass plant, but also the associated flora and fauna.

\section{Importance of bait for artisanal fisheries}

Another component of the food provisioning service associated with seagrass ecosystems is the supply of bait to artisanal fisheries. Local fishers collect their bait in the seagrass meadows and target seagrass associated fish species (de la TorreCastro \& Rönnbäck, 2004, Semesi \& Björk, 2005). About $50 \%$ of the 13 sampled species consumed "gozi", with almost $90 \%$ of the fishes caught with dema traps having "gozi" in their stomachs. Local fishers have a high degree of ecological knowledge, but evaluating and testing this knowledge is very difficult. This study provides an example of how to address and illuminate the importance of ecological knowledge in a more rigorous manner. The analysis of gear differences (dema compared to net) shows that there are possible effects when the local bait is used, for example high bait efficiency (Fig. 4 and 5). However, since gear and bait factors are confounded, complementary studies are needed to establish bait efficiency. It is also important to note that bait in the traps affects the relative abundance of the items found in the stomach of the fishes. The diets obtained by analyzing the stomach contents of fishes caught by dema should not be seen as accurate representations of natural diets; data provided by fishes caught by net gives a better representation of the fish diets in the natural environment. Additional studies that compare catches in differentially baited dema traps and longer data series analysis of fish caught with nets could shed further light on this issue. Nevertheless, this study provides an initial indicator evaluating the ecological knowledge regarding bait use. Previously, fishers have reported that the mixed "gozi" bait is very efficient to catch S. sutor and L. vaigiensis. Thus, a striking result was the clear differences observed for these two species when caught with the different gears. The food items that contribute to the differences were "gozi" for L. vaigiensis and Laurencia spp. and Ceramium spp. for S. sutor. These food items are abundant in the meadows where the bait is collected. While fishers believe that the favourite food item for fish is the sponge itself, the results suggest that it is the whole mixture of seagrass, sponge and macroalgae - and not just the sponge - that may attract different kinds of fish. Furthermore, it seems that Laurencia spp. may play a very important role in attracting the fish, something that is further supported by the existence of a local name for Laurencia spp. ("mapini") when used as bait.

Siganus sutor has a highly varied diet, while Leptoscarus vaigiensis is more selective and clearly prefers seagrasses and the sponge. Irrespective of the details, the fishers' statement that "a bunch of gozi" is important bait for these two species seems to be accurate. Furthermore "gozi" was the food item of highest abundance in the stomachs of fish caught with dema. The results also support the notion that a combination of different types of knowledge e.g. fisher's knowledge and scientific knowledge can complement each other. In this case, fishers provided general knowledge on bait use and the multivariate statistical analysis provided information about the particular contributions of bait items. Although the inclusion of traditional strategies into management is a complex issue and in some cases the positive effects are difficult to assess (McClanahan et al., 1997), combining 
different kinds of knowledge may lead to better management in general (Berkes and Folke, 1998) and it has shown to be important and beneficial in the WIO region (e.g. Obura et al., 2002; Crona, 2006; de la Torre-Castro, 2006a).

\section{Challenges for the valuation of ecosystem goods and services}

A common situation is that ecosystem goods such as fish are evaluated by using market prices. However, valuation of ecosystem services is especially difficult because they are hard to identify, quantify and they lack market values. In most cases the links between ecosystem processes and human well-being remains elusive, creating concerns for valuation efforts. In-depth ecological studies on different scales are needed to implement the concept of ecosystem services in management. For example, spatial and temporal ecosystem dynamics influence the quantity of generated goods and services, which in turn limits the potential for transferring values across time and space. Furthermore, ecosystem functions and services do not always show a one-toone correspondence. Sometimes a single ecosystem service is the product of two or more processes, whereas in other cases a single process contributes to more than one service (de Groot et al., 2002).

This study shows a way to operationalize a complex ecosystem service, i.e., food provisioning from seagrass ecosystems, which is important for both fish and humans. Using basic ecological data (stomach contents), ecological knowledge from local fishers (bait selection) and knowledge about structure of the seagrass ecosystem (data on associated plant and animal communities), the study illustrates the link between the ecosystems and the benefits. Using only fish prices as a valuation measurement for the whole ecosystem misses important aspects related to other ecosystem elements. The findings suggest that a good approach to valuation should consider a broad ecosystem perspective. The use of both utilitarian and non-utilitarian values has also been stressed (Millennium Ecosystem Assessment 2003). The findings generated by this study suggest that links between so called "hard ecological data" and broader ecosystem goods and services approaches are possible to establish. In these rural settings, in which subsistence is directly dependent on natural resources, the value of the ecosystem services cannot be trivialized. Herbivores are abundant in the catches of Chwaka Bay and they largely benefit the human population in economic and food security terms (de la Torre-Castro \& Rönnbäck 2004, de la Torre-Castro unpublished data).

Acknowledgements - We are grateful to the Institute of Marine Sciences, Zanzibar (IMS) for support in all phases of the study. Thanks to Chwaka fishermen who helped us with the fish collection and shared their vast knowledge. WIOMSA has provided valuable support and contacts. We are especially thankful to Dr. Lars Lindström who patiently helped us in the field and lab with dissection, storing and transporting of the stomachs. Katrin Österlund kindly helped us with the identification of different bait items. Dr. Nils Kautsky, Albert Norström and Angelina Sanderson Bellamy provided valuable comments on early drafts. The manuscript was greatly enhanced by the comments of two anonymous reviewers. Sida/SAREC, Swedish International Development Cooperation Agency financed this study.

\section{REFERENCES}

Almeida, A.J., Amoedo, L. \& Sadanha, L. (2001). Fish assemblages in the seagrass beds at Inhaca Island (Mozambique) - cold season. Bol. Mus. Mun. Funchal, Sup No. 6: 11-125.

Almeida, A.J., Marques, A. \& Sadanha, L. (1999). Some aspects of the biology of three fish species from seagrass beds at Inhaca Island, Mozambique. Cybium 23(4): 369-376.

Arrivillaga, A. \& Baltz, D.M. (1999). Comparison of fishes and macroinvertebrates on seagrass and bare-sand sites on Guatemala's Atlantic coast. Bull. of Marine Sciences 65(2): 301-319

Bandeira, S.O. \& Gell, F. (2003). The seagrasses of Mozambique and Southeastern Africa. In Green E. P. \& Short, F. (eds). World Atlas of Seagrasses. UNEP World Conservation.

Berkes, F. \& Folke, C. (eds) (1998). Linking social and ecological systems: Management Practices and Social Mechanisms for Building Resilience. Cambridge: Cambridge University Press.

Bologna, P.A.X. \& Heck, K.L. (1999). Macrofaunal associations with seagrass epiphytes - Relative importance of trophic and structural characteristics. J. Exp. Mar. Biol. Ecol. 242: 21-39. 
Bostrom, C. \& Bonsdorff, E. (1997). Community structure and spatial variation of benthic invertebrates associated with Zostera marina (L.) beds in the northern Baltic Sea. J. Sea Res. 37: 153-166.

Clarke, K.R. \& Warwick, R.M. (2001). Change in marine communities: an approach to statistical analysis and interpretation. $2^{\text {nd }}$ Edition. PRIMER-E. Plymouth.

Connolly, R.M. (1994). The role of seagrass as preferred habitats for juvenile Sillagonides punctata (cuv and val) (Sillaganidae, Pisces) habitat selection or feeding. J. Exp. Mar. Biol. Ecol. 180: 39-47.

Coppejans, E., Beeckman, H. \& de Wit, M. (1992). The seagrass and associated macroalgal vegetation of Gazi Bay (Kenya). Hydrobiologia 247: 59-75.

Crona, B.I. (2006). Supporting and enhancing development of heterogeneous ecological knowledge among resource users in a Kenyan seascape. Ecology and Society 11(1): 32. http:// www.ecologyandsociety.org/vol11/iss1/art32/

de Boer, W.F., van Schie, A.M.P., Jocene, D.F., Mabote, A.B.P. \& Guissamulo, A. (2001). The impact of the artisanal fishery on a tropical intertidal benthic fish community. Environmental Biology of Fishes 61: 213-229.

de Groot, R.S., Wilson M.A. \& Boumans R.M.J. (2002). A typology for the classification, description and valuation of ecosystem functions, goods and services. Ecological economics 41: 393-408.

de la Morniere, E.C., Pollux, B.J.A., Nagelkerken, I., Hemminga, M.A., Huiskes, A.H.L. \& van der Valde, G. (2003). Ontogenetic dietary changes of coral reefs fishes in the mangrove-seagrassreef continuum: stable isotopes and gut-contents analysis. Marine Ecology Progress Series 246: 279-289.

de la Torre-Castro, M. (2006). Humans and seagrasses in East Africa - A social-ecological systems approach. Doctoral Dissertation. Stockholm University, Stockholm, Sweden. On-line: http:// www.diva-portal.org/diva/getDocument?urn_ nbn_se_su_diva-1061-2_fulltext.pdf.

de la Torre-Castro, M. (2006a). Beyond regulations in fisheries management: the dilemmas of the "beach recorders" Bwana Dikos in Zanzibar, Tanzania. Ecology and Society 11(2): 35. http:www. ecologyandsociety.org/vol11/iss2/art35/

de la Torre-Castro, M. \& Rönnbäck, P. (2004). Links between humans and seagrasses - An example of tropical East Africa. Ocean \& Coastal Management 47: 361-387.

de Troch, M., Mees, J. \& Wakwabi, E. (1998). Diets of abundant fishes from beach seine catches in seagrass beds of a tropical bay (Gazi Bay, Kenya). Belg. J. Zool. 128: 135-154.

Dorenbosch, M., Grol, M. G. G., Christianen, M. J. A., Nagelkerken, I. \& van der Valde, G. (2005). IndoPacific seagrass beds and mangroves contribute to fish density and diversity on adjacent coral reefs. Marine Ecology Progress Series 302: 63-76.

Duarte, C.M. (2000). Marine biodiversity and ecosystem services: an elusive link. J. Exp. Mar. Biol. Ecol. 250: 117-131.

Eklöf, J.S., de la Torre-Castro, M., Adelsköld, L., Jiddawi, N.S. \& Kautsky, N. (2005). Differences in macrofaunal and seagrass assemblages in seagrass beds with and without seaweed farms. Est. Coast. Shelf. Sci. 63(3): 385-396.

Eklöf, J.S., de la Torre-Castro, M., Gullström, M., Uku, J., Muthiga, N., Lyimo, T., \& Bandeira, S.O. (2008). Sea urchin overgrazing of seagrasses: A review on current knowledge on causes, consequences and management. Estuarine, Coastal and Shelf Science, in Press, corrected proof, available online 21 May 2008.

Fischer, W. \& Bianchi, G. (eds.) (1984). FAO species identification sheets for fishery purposes. Western Indian Ocean (Fishing area 51). Rome, FAO. Vol. I-VI: pag. var.

Fortes, M.D. (1989). Seagrasses a resource unknown in the ASEAN region. ICLARM Education series 5. Manila, Philippines: International Center for Living Aquatic Resources Management. 46 pp.

Gell, F. \& Whittington, M.W. (2002). Diversity of fish in seagrass beds in the Quirimba Archipelago, northern Mozambique. Mar. Freshwater Res. 53: 115-121.

Green, E. P. \& Short, F. (eds) (2003). World Atlas of Seagrasses. UNEP World Conservation Monitoring Centre. Berkeley: University of California Press.

Gullström, M., de la Torre-Castro, M., Bandeira, S.O., Björk, M., Dahlberg, M., Kautsky, N., Rönnbäck, P. \& Öhman, M.C. (2002). Seagrass ecosystems in the Western Indian Ocean. Ambio 31(7-8): 588-596.

Hammar, L. (2005). Linkages between bottom structure and catch composition in defined fishing grounds of the seagrass fishery in Chwaka Bay, Zanzibar. Master Thesis. Stockholm University. Stockholm, Sweden.

Hemminga, M.A. \& Duarte, C.M. (2000). Seagrass Ecology. Cambridge: Cambridge University Press.

Hindell, J.S., Jenkins, G.P. \& Keough, M.J. (2000). Evaluating the impact of predation by fish on the assemblage structure of fishes associated with seagrass (Heterozostera tasmanica) (Martens ex 
Ascherson) den Hartog, and unvegetated sand habitats. J. Experimental Marine Biology Ecology 255(2): 153-174.

Hyslop, E.J. (1980). Stomach content analysis - a review of methods and their application. J. Fish Biol. 17: 411-429.

Jiddawi, N.S. \& Öhman, M.C. (2002). Marine fisheries in Tanzania. Ambio 31(7-8): 518-27.

Lugendo, B.R., Nagelkerken, I., van der Velde, G. \& Mgaya, D. (2006). The importance of mangroves, mud and sand flats, and seagrass beds as feeding areas for juvenile fishes in Chwaka Bay, Zanzibar: gut content and stable isotope analyses. Journal of Fish Biology 69: 1639-1661.

Millennium Ecosystem Assessment (2003). Ecosystems and human well-being a framework for assessment. World Resources Institute. Island Press, Washington.

McClanahan, T.R., Glaesel, J., Rubens, J. \& Kiambo, R. (1997). The effects of traditional fisheries management on fisheries yields and the coralreef ecosystems of Southern Kenya. Env. Cons. 24: 105-120.

Nakamura, Y., Horinouchi, M., Nakai, T. \& Sano, M. (2003). Food habits of fishes in a seagrass bed on a fringing coral reef at Iriomote Island, southern Japan. Ichthyological Research 50: 15-22.

Obura, D.O., Wells, S., Church, J. \& Horrill, C. (2002). Monitoring of fish and fish catches by local fishermen in Kenya and Tanzania. Mar. Freshwater Res. 53: 215-222.

Ochieng, C.A. \& Eftermeijer P.L.A. (1999). Accumulation of seagrass beach cast along the Kenyan coast: a quantitative assessment. Aquatic Botany 65: 221-238.

Oliveira, E.C., Österlund, K, \& Mtolera, M. (2005). Marine Plants of Tanzania. Stockholm: Stockholm University, 267 pp.

Paula, J., Costa, P.F.E., Martins, A. \& Gove, D. (2001). Patterns of abundance of seagrasses and associated infaunal communities at Inhaca Island, Mozambique. Estuarine Coastal and Shelf Sciences 53(3): 307-318.

Richmond, M.D. (ed.) (1997). A guide to the seashores of Eastern Africa and the Western Indian Ocean Islands. Sida/SAREC. Stockholm, Sweden.

Salita, J.T., Ekau, W. \& Saint-Paul, U. (2003). Field evidence on the influence of seagrass landscapes on fish abundance in Bolinao, northern Philippines. Marine Ecology Progress Series 247: 183-195.

Semesi, A.K. (1988). Seasonal changes in macroepiphytes on Thalassodendron ciliatum (Forsk) den Hartog at Oyster Bay, Dar-es-Salaam, Tanzania. In Mainoya, J.R. (ed). Proceedings of a workshop on ecology and bioproductivity of marine coastal waters of Eastern Africa. Dar-esSalaam, Tanzania. Faculty of Science, University of Dar-es-Salaam. 51 - 58.

Semesi, S. \& Björk, M. (2005). Use of seaweeds in traditional fishing activities in Tanzania. Abstract and lecture for the Fourth WIOMSA scientific symposium. Grand Baie, Mauritius. 30 August-1 September 2005.

Smith M.M., \& Heemstra P.C. (eds.) (1986). Smith's Sea Fishes. McMillan, Johannesburg. 1047 pp.

Somerfield, P.J., Yodnarasri, S. \& Aryuthaka, C. (2002). Relationships between seagrass biodiversity and infaunal communities: implications for studies of biodiversity effects. Mar. Ecol. Prog. Ser. 237: 97-109.

Terashima H., Mosaheb J.I., Paupiah C.N. \& Chineah V. (2001). Field Guide to Coastal Fishes of Mauritius. Albion Fisheries Research Centre, Ministry of Fisheries. Albion, Petite Riviere, Mauritius.

Uku, J. (2005). Seagrasses and their epiphytes: characterization of abundance and productivity in tropical seagrass beds. Doctoral dissertation. Stockholm University. Stockholm, Sweden.

Uku, J. \& Björk, M. (2001). The distribution of epiphytic algae on three Kenyan seagrass species. South African Journal of Botany 67(3): 475-482.

Uku, J. \& Björk, M. (2005). Productivity aspects of three tropical seagrass species in areas of different nutrient levels in Kenya. Estuarine, Coastal and Shelf Science 63: 407-420.

URT, Government of Tanzania. (2002). Population and Housing Census.http://www.tanzania.go.tz/ census/districts/central.htm.

Valentine, J.F., Kenneth, L., Heck Jr, K. L. \& Cinkovish, A.M. (2002). Impacts of seagrass food webs on marine ecosystems: a need for a broader perspective. Bulletin of Marine Science 7(3): 1361-1368.

Webster, P.J., Rowden, A.A. \& Attrill, M.J. (1998). Effect of shoot density on the infaunal macroinvertebrate community within a Zostera marina seagrass bed. Estuarine, Coastal and Shelf Science 47(3): 351-357.

Whitfield A.K (1998). Biology and Ecology of Fishes in Southern African Estuaries. J.L.B. Smith Institute of Ichthyology. Grahamstown, South Africa

www. fishbase.org (2007). Froese, R. and D. Pauly. Editors. FishBase. World Wide Web electronic publication. www.fishbase.org, version (05/2007). 